ERIA - DP - 2009-21

ERIA Discussion Paper Series

\title{
Resiliency of Production Networks in Asia: Evidence from the Asian Crisis
}

\author{
Ayako OBASHI ${ }^{\dagger}$ \\ Faculty of Economics, Keio University
}

October 2009

\begin{abstract}
This paper presents the resiliency of international production networks stretched across the Asian region in face of the Asian financial and currency crisis back in 1997-98, as well as confirming its stability with consideration to adverse effects of the crisis. To examine the probability of survival once a trade relationship is established and the probability of revival after the transaction is broken off, survival analysis is conducted using the country-product level trade data. A series of survival analyses provide evidence supporting the view that transactions of intermediate goods within production networks are more likely to be stable and resilient to a temporary disruption compared to other transactions. First, even after considering the impact of the Asian crisis, machinery parts \& components are more likely to be traded through long-lived trade relationships compared to finished products in intra-Asian trade. Second, machinery parts \& components are no exception in that a non negligible portion of trade relationships was actually broken off amid the Asian crisis, but many of them were restored shortly afterward as compared to the others.
\end{abstract}

Keywords: Duration of trade; fragmentation; the Asian crisis

JEL Categories: F10; F14

\footnotetext{
* The author would like to thank Professor Fuku Kimura for helpful comments.

$\dagger$ Ayako Obashi. Faculty of Economics, Keio University, 2-15-45 Mita, Minato-ku, Tokyo 108-8345, Japan. Phone: +81-3-3453-4511. E-mail: aobashi@gs.econ.keio.ac.jp.
} 


\section{Introduction}

Amid the latest global crisis, economic downturn in the US and Europe has transmitted to Asian countries primarily through the trade channel rather than financial channel. Concern is greatest for adverse effects of the crisis on the actual flow of goods, which will decelerate GDP growth throughout the region as a result of a sharp decline in demand for exports by Asian countries. The export-oriented manufacturing industries and countries dependent on them have been hit the hardest as of the end of 2008, according to ADB (2009). The latest global crisis, of course, does not stem from international production networks, but there is rising concern that the adverse impact of the crisis will spread through such networks. The more interdependent countries are, the more quickly an economic shock originating in one country is transmitted to another. Mutual ties built through production chains would bring a synchronized contraction of trade flows across countries taking part in production networks; however, trade relationships within the networks appear to be resilient to the shocks due to relation-specific nature of the transactions. This paper investigates such resiliency of production networks stretched across the Asian region in face of the Asian financial and currency crisis back in 1997-98.

Asian countries have expanded and deepened intra-regional trade relationships since the beginning of the 1990s. Regional diversity in income levels and development stages promotes opportunities for multinational enterprises to locate fragmented production blocks in different locations with different location advantages all over the Asian region. ${ }^{1}$ In particular, the machinery industry extends the most sophisticated networks (See Fukao et al., 2003; Athukorala and Yamashita, 2006; Kimura, 2006), and the increasing importance of exports and imports of machineries are evident for each of Asian countries. In the light of the unprecedented development of production networks along with active back-and-forth transactions of machinery parts \& components, this paper basically examines intra-Asian trade relationships of machinery parts \& components, in comparison with those of finished products, so as to look into

\footnotetext{
${ }^{1}$ For the fragmentation theory, see Jones and Kierzkowski (1990), Arndt and Kierkowski (2001), and Deadorff (2001). In terms of international production networks in Asia, Kimura and Ando (2005) claim the two-dimensional concept of fragmentation.
} 
unexplored natures of production networks in the region.

The goal of this paper is to shed light on the resiliency of international production networks amid the Asian crisis as well as confirming its stability with consideration to adverse effects of the crisis. To this end, survival analysis is conducted using highly disaggregated trade data at the country-product level, which enables us to reveal the probability of survival once a trade relationship is established and the probability of revival after the transaction is broken off. A series of survival analyses provide an evidence to support the stability of the transactions of intermediate goods within production networks in Asia and its resiliency to a temporary disruption due to economic shocks. First, even after considering the impact of the Asian crisis, machinery parts \& components are more likely to be traded through long-lived trade relationships compared to finished products in intra-Asian trade. Second, in face of the Asian crisis, the discontinued trade relationships of parts \& components are more likely to be restored shortly compared to those of finished products as well as the case of transactions that were discontinued at times other than the crisis.

This paper offers an additional insight to Obashi (2009), who clarifies the stability of transactions of intermediate goods within international production networks compared to the other transactions. It also contributes to a pioneering work on duration of trade by Besedeš and Prusa (2006a; 2006b), from the perspective of international fragmentation of production. Besedeš and Prusa (2006a), who first investigated the duration of the US imports, find the country-product-level trade to be surprisingly volatile with the median duration of four years. As their companion paper, Besedeš and Prusa (2006b) highlight that differentiated products have a longer median duration and a higher probability of survival than homogeneous products, based on a search cost model of international trade. Besedeš (2008) provides additional facts on the survival of the US imports from the search cost perspective. The prevalence of short-lived trade relationships has been also found in Blyde (2008) for exports by Latin American countries, Nitch (2009) for German imports, and Obashi (2009) for intra-Asian trade in machineries.

The rest of this paper proceeds as follows: the next section examines the probability of the survival of trade relationships, employing the Kaplan-Meier method and the Cox proportional hazard model as well as outlining the duration of trade for intra-Asian trade 
in machineries. Considering effects of the Asian crisis, Section 3 confirms that machinery parts \& components have a higher probability of survival than finished products, and examines the probability of revival at the time of the Asian crisis. The interpretation of the empirical findings and their implication for the latest global crisis are discussed in Section 4. And the last section concludes.

\section{Survival of Trade Relationships in Intra-Asian Machinery Trade}

To examine trade relationships in intra-Asian trade, this paper uses bilateral trade data at the 6-digit level of Harmonized System (HS) 1992 from 1993 to 2007 obtained from the United Nations Commodity Trade Statistics Database (UN Comtrade). ${ }^{2}$ The HS 6-digit level is the most detailed disaggregated level of trade data that is internationally comparable and publically available. At the 6-digit level of HS 1992, there exist 4,013 product lines for all manufacturing industries (HS28-92) and 1124 for machinery industry (HS84-92), the latter of which are grouped into 436 parts \& components and 688 finished products, following Ando and Kimura (2005). Asia here includes 14 countries, namely, ASEAN (Brunei, Cambodia, Indonesia, Laos, Malaysia, Myanmar, the Philippines, Singapore, Thailand, and Viet Nam), China, Hong Kong, Japan, and Rep. of Korea. Eight out of the 14 Asian countries have reported trade statistics according to the HS classification throughout the period. Dataset is created by using import as well as export statistics reported by those eight countries, and consists of 152 (= 14 countries * 13 - 6 non-reporting countries * 5) exporter-importer pairs.

\subsection{Duration of Trade}

For each exporter-importer-product pair, whether a trade relationship is active in a given year and how long a trade relationship is continued without interruption can be identified. Table 1 reports the basic statistics for the number of years in which a trade relationship is active during 1993-2007 (15 years) for intra-Asian trade. The figures

\footnotetext{
${ }^{2}$ See Appendix A for the details of trade data used throughout this paper.
} 
for machinery parts \& components are compared with those for finished products and other manufactured goods. Trade relationships of parts \& components are more active than those of finished goods as well as other manufactured goods. For the observed exporter-importer-product pairs excluding those inactive throughout the period, the mean number of years active is 9.2 for parts \& components, which is $1.5-1.7$ points higher than finished products and other manufactured goods.

Table 1. Number of Years Active During 1993-2007 for Exporter-importer-product Pairs.

\begin{tabular}{c|c|c|c|c|c|c|c|c}
\hline \hline & Mean & Median & \multicolumn{2}{|c|}{$\begin{array}{c}\text { Cumulative percentages (\%) } \\
\text { by number of years active }\end{array}$} & Obs. & $\begin{array}{c}\text { Share (\%) in } \\
\text { the max. } \\
\text { possible N. }\end{array}$ & $\begin{array}{c}\text { N. of } \\
\text { product } \\
\text { lines }\end{array}$ \\
\cline { 4 - 6 } & & 1 & 7 & 14 & & 60.6 & 1,124 \\
Machineries & 8.3 & 8 & 14.3 & 47.3 & 76.3 & 103,454 & 64.7 & 436 \\
P \& C & 9.2 & 10 & 11.4 & 39.8 & 69.6 & 42,893 & 67.9 & 688 \\
FP & 7.7 & 7 & 16.3 & 52.6 & 81 & 60,561 & 57.9 & 2,889 \\
Other Manuf. & 7.5 & 7 & 16.3 & 53.8 & 81.7 & 231,927 & 52.8 & 2.8 \\
\hline \hline
\end{tabular}

Note: The number of exporter-importer pairs in the sample of Asian countries is 152 . Inactive trade relationships throughout 1993-2007 are not included in the above basic statistics.

The above result can be interpreted as a reflection of the difference in the duration of trade relationships. Our interest is then turned towards the length of time a certain product is continuously traded between an exporter-importer pair. For instance, if country $i$ started to export product $h$ to country $j$ in 1994 and ceased to export the product in 1998, the trade relationship is regarded as having a spell length of four. As some of trade relationships were broken off and restored after a certain period, at least a year, which is referred to as multiple spells, the number of spells by exporter-importer-product pair as well as the length of each spell should be examined.

Tables 2 and 3 report the basic statistics for the number of spells and for their lengths, respectively. ${ }^{3} \quad$ Even with aggregated trade data at the country level rather than data on the firm-level export activities, the break and restoration of trade relationships occur at significant frequency. In particular, for machinery finished products, 54 percent of exporter-importer-product pairs experience multiple spells, more than half of which, 29 percent experience more than two spells. In addition, short-lived trade relationships are more prevalent than expected particularly for finished products. The

\footnotetext{
${ }^{3}$ As multiple spells are treated as independent, the size of observations in Table 3 is larger than that in Table 2.
} 
mean length of spells is 3.9 years for finished products, which is 1.2 years shorter than parts \& components.

Table 2. Number of Spells for Exporter-importer-product Pairs.

\begin{tabular}{l|c|c|c|c|c|c|c}
\hline \hline & \multirow{2}{*}{ Mean } & \multirow{2}{*}{ Median } & \multicolumn{2}{|c|}{ Cumulative percentages (\%) by number of spells } & \multirow{2}{*}{ Obs. } \\
\cline { 4 - 7 } & & & 1 & 2 & 3 & 4 & \\
\hline Machineries & 1.91 & 2 & 48.8 & 73.2 & 89.8 & 97.6 & 103,454 \\
P \& C & 1.81 & 1 & 53.4 & 76.6 & 91.5 & 98.1 & 42,893 \\
FP & 1.98 & 2 & 45.6 & 70.8 & 88.6 & 97.2 & 60,561 \\
Other Manuf. & 1.88 & 2 & 48.2 & 74.6 & 91.2 & 98.2 & 231,927 \\
\hline \hline
\end{tabular}

Note: Exporter-importer-product pairs of active trade relationships only.

Table 3. Length of Spells for Bilateral Trade Relationships at the Product-line Level.

\begin{tabular}{|c|c|c|c|c|c|c|c|c|}
\hline & \multirow{2}{*}{ Mean } & \multirow{2}{*}{ Median } & \multicolumn{5}{|c|}{ Cumulative percentages (\%) by number of spells } & \multirow{2}{*}{ Obs. } \\
\hline & & & 1 & 2 & 4 & 7 & 10 & \\
\hline Machineries & 4.4 & 2 & 44.3 & 59.0 & 71.0 & 79.9 & 83.7 & 197,561 \\
\hline $\mathrm{P} \& \mathrm{C}$ & 5.1 & 2 & 39.4 & 53.1 & 65.0 & 74.2 & 78.4 & 77,514 \\
\hline FP & 3.9 & 2 & 47.5 & 62.8 & 74.9 & 83.6 & 87.1 & 120,047 \\
\hline Other Manuf. & 4.0 & 2 & 45.4 & 60.9 & 73.7 & 82.4 & 86.5 & 436,263 \\
\hline
\end{tabular}

Note: Active trade relationships only.

\subsection{Kaplan-Meier Estimation}

Stimulated by the facts that machinery parts \& components are likely to be traded through more stable relationships without interruption for a longer period of time compared to finished products as well as other manufactured goods, this and the next subsections perform survival analysis. As a first step, this subsection highlights the difference in the probability of the survival of trade relationships between machinery parts \& components and finished products, employing the Kaplan-Meier method. As a second step, the next subsection confirms the difference in the probability of survival, employing the Cox proportional hazard model.

Estimated Kaplan-Meier survival rates for bilateral trade relationships at the product-line level in intra-Asian trade in machineries are reported in Table 4, and the corresponding survival functions and hazard functions are graphed in Figure $1 .^{4}$ The

\footnotetext{
4 The survival function is estimated nonparametrically using the Kaplan-Meier product limit estimator, along the lines of Besedeš and Prusa (2006a) and other previous studies. The hazard function is estimated using the usual smoothing Kernel (epanechnikov) technique with a limited graphing range. The survival function of $T$, the time to failure event, is given by $S(t)=\operatorname{Pr}(T>t)$. $S(t)$ equals one at $t=0$ and decreases towards zero as $t$ increases. The hazard function is given by $h(t)=\operatorname{Pr}(T=t \mid T \geq t)$. The survival and hazard functions are just alternative ways to express the same
} 
estimates for parts \& components are compared with those for finished products. ${ }^{5}$

Table 4. Estimated Kaplan-Meier Survival Rates for Intra-Asian Trade in Machineries.

\begin{tabular}{l|c|c|c|c|c|c}
\hline \hline & \multicolumn{5}{|c|}{ Estimated K-M survival rate } & \multirow{2}{*}{ Obs. } \\
\cline { 2 - 6 } & $1^{\text {st }}$ year & $2^{\text {nd }}$ year & $4^{\text {th }}$ year & $7^{\text {th }}$ year & $10^{\text {th }}$ year & \\
\hline P\&C & 0.65 & 0.53 & 0.43 & 0.38 & 0.36 & 77,514 \\
FP & 0.58 & 0.44 & 0.33 & 0.26 & 0.24 & 120,047 \\
\hline \hline
\end{tabular}

Note: The difference of survival function between parts \& components and finished products is significant at the $1 \%$ level using the log-rank test.

Figure 1. Kaplan-Meier Estimates of Survival Functions and Hazard Functions for Intra-Asian Trade in Machineries.
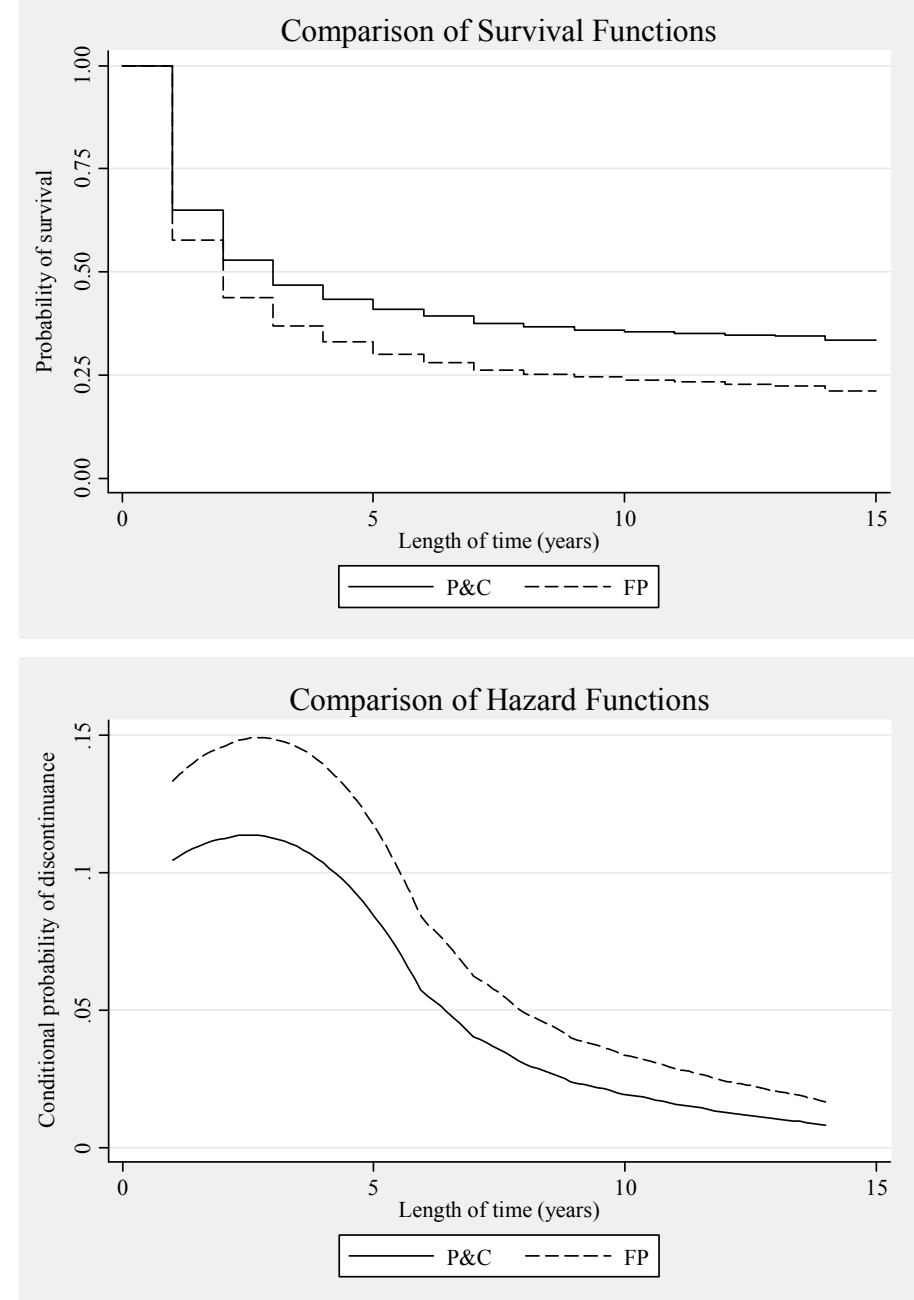

underlying failure process.

${ }^{5}$ As a reference, the Kaplan-Meier estimates for machineries including both parts \& components and finished products, in comparison with those for other manufactured goods, are reported in Table A1 and Figure A1. 
The shape of the estimated survival functions for parts \& components and finished products look similar. Both curves are downward sloping with a decreasing slope. A substantial portion of trade relationships fail within the first four years, especially in the first year when the survival rates, i.e., the probability of survival, are $65 \%$ and $58 \%$ for parts \& components and finished products, respectively. For the later years, on the other hand, the survival rates slowly decline by only $5-7 \%$ between the fourth and seventh years, and remain nearly constant afterwards. ${ }^{6}$ As evidenced by the shape of the estimated hazard functions, a kind of threshold effect is observed. The hazard rate, i.e., the conditional probability of discontinuance, is maintained at a high level in the earlier years, but then sharply decreases once a trade relationship lasts for a certain period of time. To be more precise, the hazard rate is the probability that a particular product will not be traded between an exporter-importer pair in the $t$-th year given that it has been traded until the previous year.

The survival curves are similar in shapes, but the survival rates are higher for parts \& components than finished products at any point of time. Such a difference is reflected in the result that the hazard rates are lower for parts \& components than finished products though the hazard curves tend to converge as trade relationships last longer. In addition, the distance between the survival curves is widening in the earlier years as finished products are at an increased hazard rate while parts \& components maintains a relatively constant rate.

These features are robust though estimated survival rates vary among different samples (See Table A1 and Figure A1). First, to address the left-censoring issue, survival functions are re-estimated for the sample without spells that begun in 1993. Second, survival functions are estimated using a modified sample, in which the length and number of spells are adjusted by assuming that a one-year gap between spells that last at least two years is a result of a recording error, as pointed out by Besedeš and Prusa $(2006 a ; 2006 b) .^{7}$ For a reference, survival functions are also estimated only for the first spells of respective exporter-importer-product pairs and for single spells, and

\footnotetext{
${ }^{6}$ Spells ended in 2007, the end year of the sample, are classified as right-censored, i.e., continued, rather than failures, i.e., discontinued. It must be appropriate to interpret the length of the right-censored spells as a minimum.

${ }^{7}$ A one-year gap may be partly due to a discrete nature of trade data which is compiled on an annual basis.
} 
the aforementioned features still hold. Furthermore, these features are not limited to intra-Asian trade (See Table A2 and Figure A2).

\subsection{Cox Proportional Hazards Estimation}

In order to confirm the difference in the probability of survival between machinery parts \& components and finished products, the Cox proportional hazards model is estimated, considering country-specific and pair-specific characteristics that may influence the duration of trade. The semi-parametric Cox proportional hazards model asserts that the hazard rate for the $m$-th subject in the sample is

$$
h\left(t \mid \boldsymbol{x}_{\boldsymbol{m}}\right)=h_{0}(t) \exp \left(\boldsymbol{x}_{\boldsymbol{m}} \boldsymbol{\beta}\right)
$$

where $\boldsymbol{x}_{\boldsymbol{m}}$ denotes a vector of $\boldsymbol{m}$-th subject's covariates and coefficients $\boldsymbol{\beta}$ are to be estimated. $^{8}$ The Cox model is by far the most popular choice in the analysis of survival data. A particular advantage of the model is that the baseline hazard function, $h_{0}(t)$, is left unspecified and not estimated. What is assumed is that the covariates multiplicatively shift the baseline hazard which is common to all the subjects. ${ }^{9}$ The hazard rate for individual subject equals to the baseline hazard when the value of all covariates is set to zero. Exponentiated respective coefficients are then interpreted as the ratio of the hazard rates, which is referred to as hazard ratio, for a one-unit change in the corresponding covariate. Hazard ratio is greater than one if the corresponding covariate negatively affects the duration of trade, and vice versa. A ratio equal to one implies no impact on the duration of trade.

To estimate the Cox model using time-dependent covariates, the survival data are split at every observed failure time, i.e., at every year, for respective spells. As for country-year-specific characteristics, exporter country's GDP and importer country's GDP are included as standard gravity variables of economic size. ${ }^{10,11}$ Supplier firms

\footnotetext{
${ }^{8}$ As the Cox model is a continuous model while the survival data used in this paper is on an annual basis, in which some failures occur at the same survival time (year), the Breslow (1974)'s approximation is assumed so as to treat tied failures.

9 In this regard, however, estimation is to be stratified by machinery subsector, i.e., general machinery (HS84), electric machinery (HS85), transport equipment (HS86-89), and precision machinery (HS90-92), allowing the baseline hazard to vary among strata.

${ }_{11}$ See Appendix B for the data sources of covariates.

${ }^{11}$ We would prefer value added of machinery industry of its own (ideally, disaggregated by product type) to GDP as a variable indicating the size of economic activities of machinery industry. Due to
} 
located in larger economies might be able to maintain a longer trade relationship due to larger production capacities. Meanwhile, a larger pool of potential buyers might ease accommodating demand fluctuation through switching buyers within a country, leading to a longer trade relationship at the country level.

As for pair-year-specific characteristics, the absolute value of the difference in per capita GDP between exporter and importer countries is included as a proxy for wage differential, which may reflect different factor intensity, or production technology, and factor endowment. These differences in production conditions are presumed to encourage cross-border production sharing, leading to a longer-lasting trade relationship. To capture supplier firm's competitiveness in terms of relative trading cost, the year-on-year percentage change in real exchange rate (RER) for exporter country's currency to importer country's currency is included. An increase in RER reflects that an exporter country's currency has weakened relative to importer country's currency with consideration to inflation in respective economies. If an exporter country's currency depreciates, since its supplier firms will become more competitive relative to those located in the export counterpart, the suppliers might be less likely to exit from the market.

To control for the initial size of transaction, the logarithm of trade value in the first year is included. A trade relationship started with a smaller trade value at the country level, which is probably economically less important for either or both exporter and importer countries in the beginning, may face a greater risk of discontinuance. Regarding the prevalence of multiple spells, a dummy variable for subsequent spells is included, following Besedeš and Prusa (2006b). Although multiple spells are treated as independent because separated spells are highly likely to involve different firms of exporter and importer countries, the probability of survival will depend on the experience of discontinuance. A trade relationship restarted after a certain period of no trade may not fail again, owing to accumulated information about the trade counterpart at the country level. Besides these two control variables, country, country-pair, and year fixed effects are included to control for unobserved characteristics. Standard errors are clustered at the HS 6-digit product level, allowing for possible correlation 
within products.

Table 5 provides the Cox proportional hazards estimates for intra-Asian trade in machineries. Our interest here is estimated coefficients for a dummy variable which takes a value of one if a trade relationship is of parts \& components. The sample of interest is listed at the top of each column, and the covariates and control variables are in the first left column of the table. Units in which respective variables are measured are in parentheses. $^{12}$ Estimated coefficients are expressed in terms of hazard ratios.

Table 5. Cox Proportional Hazards Estimates for Intra-Asian Trade in Machineries.

\begin{tabular}{l|c|c|c|c|c|c}
\hline \hline Samples & All spells & $\begin{array}{c}\text { Without } \\
\text { 1993-origin } \\
\text { spells }\end{array}$ & $\begin{array}{c}\text { 1-year-gap- } \\
\text { adjusted }\end{array}$ & $\begin{array}{c}\text { The first } \\
\text { spells only }\end{array}$ & $\begin{array}{c}\text { Single spells } \\
\text { only }\end{array}$ & Excl. Japan \\
\hline P\&C dummy & $0.725^{* *}$ & $0.790^{* *}$ & $0.734^{* *}$ & $0.702^{* *}$ & $0.623^{* *}$ & $0.734^{* *}$ \\
Exporter's GDP (100bil US\$) & $(0.014)$ & $(0.012)$ & $(0.014)$ & $(0.016)$ & $(0.026)$ & $(0.015)$ \\
& $0.952^{* *}$ & $0.919^{* *}$ & $0.956^{* *}$ & $0.968^{* *}$ & $1.042^{* *}$ & $0.944^{* *}$ \\
Importer's GDP (100bil US\$) & $(0.002)$ & $(0.002)$ & $(0.002)$ & $(0.003)$ & $(0.007)$ & $(0.002)$ \\
Abs. diff. in PCGDP (1,000 US\$) & $0.989^{* *}$ & $0.953^{* *}$ & $0.993^{* *}$ & $0.988^{* *}$ & $1.025^{* *}$ & $0.989^{* *}$ \\
& $(0.002)$ & $(0.002)$ & $(0.002)$ & $(0.004)$ & $(0.005)$ & $(0.002)$ \\
\% change in RER (10\%) & $0.961^{* *}$ & $0.935^{* *}$ & $0.964^{* *}$ & $0.982^{* *}$ & $0.984^{* *}$ & $0.974^{* *}$ \\
& $(0.002)$ & $(0.002)$ & $(0.002)$ & $(0.003)$ & $(0.004)$ & $(0.002)$ \\
Log of initial trade value (US\$) & $0.985^{* *}$ & $0.978^{* *}$ & 0.999 & $0.984 * *$ & $1.025^{* *}$ & $0.983^{* *}$ \\
& $(0.002)$ & $(0.003)$ & $(0.002)$ & $(0.003)$ & $(0.007)$ & $(0.003)$ \\
Subsequent spells dummy & $0.854^{* *}$ & $0.917^{* *}$ & $0.866^{* *}$ & $0.830^{* *}$ & $0.867^{* *}$ & $0.868^{* *}$ \\
& $(0.003)$ & $(0.002)$ & $(0.003)$ & $(0.003)$ & $(0.006)$ & $(0.003)$ \\
\hline N. of failures & $0.720^{* *}$ & $0.793^{* *}$ & $0.820^{* *}$ & & & $0.707^{* *}$ \\
\hline \hline Log likelihood & $(0.005)$ & $(0.005)$ & $(0.005)$ & & & $(0.005)$ \\
\hline Notes: & 822,746 & 373,260 & 837,904 & 580,046 & 454,917 & 613,416 \\
\hline
\end{tabular}

Notes: The sample of interest is listed at the top of each column and the covariates are in the first left column. Coefficients are expressed as hazard ratios. Robust standard errors clustered by product are in parentheses. $\quad * *$ and $*$ indicate significance at the $1 \%$ and $5 \%$ level. All regressions include country, country-pair, and year fixed effects, but those coefficient estimates are not reported for brevity. The estimates are stratified by machinery subsectors. Multiple spells of respective exporter-importer-product pairs are treated as independent. Trade data and GDP data are in constant 2000 U.S. dollars.

12 The unit in which a variable is measured makes no substantive difference. 
The result for all the observed spells during 1993-2007 reported in the second left column of the table confirms the difference in the probability of survival by product type. With allowing trade relationships of finished products to be the benchmark, those of parts \& components have a $27 \%$ lower hazard rate. In other words, for parts \& components, once a trade relationship is developed, it is $27 \%$ less likely to be broken off. As for effects of other covariates on the hazard rate, all of them are estimated as expected.

As with the last subsection, the same Cox model is re-estimated using two different samples as a robustness check. One is the sample without 1993-origin spells, and the other is the modified sample with the one-year-gap adjustment. The estimates are qualitatively similar to the result for all the observed spells. For further reference, the estimates for the first spells sample, the single spells sample, and the sample excluding Japan are reported in the right three columns of the table. The patterns of estimated coefficients remain unchanged, except for the result for the single spells sample, and trade relationships of parts \& components are less likely to be discontinued in each sample. By focusing only on single spells, the coefficients for both exporter's GDP and importer's GDP become more than one, which seem to be due in part to multicolinearity issue.

\section{Effects of the Asian Crisis}

For intra-Asian trade in machineries, we have found that parts \& components are more likely to be traded through long-lived relationships compared to finished products. In this section, the higher probability of survival for parts \& components is to be confirmed even after considering effects of the Asian currency and financial crisis in 1997-98, in order to derive implications for the current global economic downturn.

\subsection{The Impact on the Survival of Trade Relationships}

Among all the observed trade relationships, the proportion of the trade relationships that had been active until 1997 but were discontinued in 1998, after the outbreak of the 
Asian crisis, is notably higher than average. The proportion of the trade relationships that are observed in 1997 and continued or discontinued in 1998 is reported in Table 6, compared with the corresponding average figure for the rest of sample period. The proportions of the discontinued trade relationships have hovered around $13 \%$ and $20 \%$ for machinery parts \& components and finished products, respectively; however, the figures for the year 1997 are exceptionally high, at 16\% and 24\%. Although the discontinuance share is lower for parts \& components than finished products even in 1997, the discontinuance share is markedly increased not only for finished products but for parts \& components. This fact appears to be due mostly to the Asian crisis and suggests the need for controlling effects of the crisis to bear out the stability of production networks in the Asian region.

Table 6. Number of Trade Relationships Continued/Discontinued in the Next Year.

\begin{tabular}{|c|c|c|c|c|c|c|c|}
\hline \multicolumn{4}{|c|}{$\mathrm{P} \& \mathrm{C}$} & \multicolumn{4}{|c|}{ FP } \\
\hline \multicolumn{2}{|c|}{$\begin{array}{l}\text { Continued in } \\
\text { the next year }\end{array}$} & \multicolumn{2}{|c|}{$\begin{array}{l}\text { Discontinued } \\
\text { (no trade) in } \\
\text { the next year }\end{array}$} & \multicolumn{2}{|c|}{$\begin{array}{l}\text { Continued in } \\
\text { the next year }\end{array}$} & \multicolumn{2}{|c|}{$\begin{array}{l}\text { Discontinued } \\
\text { (no trade) in } \\
\text { the next year }\end{array}$} \\
\hline $\mathrm{N}$ & Share $(\%)$ & $\mathrm{N}$ & Share $(\%)$ & $\mathrm{N}$ & Share $(\%)$ & $\mathrm{N}$ & Share $(\%)$ \\
\hline \multicolumn{8}{|c|}{ Trade relationships active in 1997} \\
\hline 21,766 & 84.0 & 4,133 & 16.0 & 23,347 & 75.8 & 7,462 & 24.2 \\
\hline \multicolumn{8}{|c|}{ Average value in the rest of sample period } \\
\hline 23,373 & 87.1 & 3,352 & 12.9 & 25,338 & 80.3 & 6,027 & 19.7 \\
\hline
\end{tabular}

In the light of possible effects of the Asian crisis on the probability of the survival of trade, Table 7 reviews the Cox proportional hazard estimates presented in Table5. The same Cox model is re-estimated using the sample excluding the trade relationships that had been active until 1997 but were discontinued in 1998 as well as a limited sample including only trade relationships that were started in and after 1998. All the estimated coefficients are qualitatively unchanged from the result for all the observed spells, except that the coefficient for the year-on-year percentage changes in RER becomes more than one in the result for the latter limited sample. Still, even after considering the impact of the Asian crisis, trade relationships of parts \& components face a 21-28\% lower hazard rate with respect to those of finished products in intra-Asian trade in machineries. 
Table 7. Robustness Check for the Cox Proportional Hazards Estimates: Effects of the Asian Crisis.

\begin{tabular}{l|c|c}
\hline \hline Sariables & $\begin{array}{c}\text { Excl. trade relationships ceased in } \\
\text { P\&C dummy }\end{array}$ & $\begin{array}{c}\text { Trade relationships started in and } \\
\text { after 1998 only }\end{array}$ \\
\hline Exporter's GDP & $0.772^{*}$ & $0.794^{* *}$ \\
& $(0.015)$ & $(0.013)$ \\
Importer's GDP & $0.948^{* *}$ & $0.895^{* *}$ \\
& $(0.002)$ & $(0.003)$ \\
Abs. diff. in PCGDP & $0.988^{* *}$ & $0.927^{* *}$ \\
& $(0.002)$ & $(0.003)$ \\
\% change in RER & $0.958^{* *}$ & $0.902^{* *}$ \\
& $(0.002)$ & $(0.002)$ \\
Log of initial trade value & $0.994^{* *}$ & $1.013^{* *}$ \\
& $(0.002)$ & $(0.004)$ \\
Subsequent spells dummy & $0.853^{* *}$ & $0.920^{* *}$ \\
& $(0.003)$ & $(0.002)$ \\
\hline Obs. & $0.745^{* *}$ & $0.777^{* *}$ \\
N. of spells & $(0.005)$ & $(0.006)$ \\
N. of failures & 799,676 & 235,278 \\
Log likelihood & 173,772 & 98,402 \\
\hline \hline
\end{tabular}

Note: See notes of Table 5 .

\subsection{Revival of Trade Relationships amid the Asian Crisis}

Next, looking into the trade relationships that were discontinued sometime during 1994-2007, the failure rate, i.e., the probability of revival, is examined. ${ }^{13}$ Estimated Kaplan-Meier failure rates are reported in Table 8 and the corresponding failure functions and hazard functions are graphed in Figure 2. The estimates for the trade relationships discontinued in 1998 are compared with those for the trade relationships discontinued in the rest of sample period, in addition to the comparison between parts \& components and finished products.

${ }^{13}$ Failure function, $F(t)$, equals $1-S(t)$, where $S(t)$ is survival function. 
Table 8. Estimated Kaplan-Meier Failure Rates for Intra-Asian Trade in Machineries.

\begin{tabular}{|c|c|c|c|c|c|}
\hline & \multicolumn{4}{|c|}{ Estimated K-M failure rate } & \multirow{2}{*}{ Obs. } \\
\hline & $1^{\text {st }}$ year & $2^{\text {nd }}$ year & $4^{\text {th }}$ year & $7^{\text {th }}$ year & \\
\hline \multicolumn{6}{|c|}{ Trade relationships discontinued in 1998} \\
\hline $\mathrm{P} \& \mathrm{C}$ & 0.41 & 0.59 & 0.75 & 0.85 & 4,113 \\
\hline FP & 0.97 & 0.54 & 0.72 & 0.82 & 7,462 \\
\hline \multicolumn{6}{|c|}{ Trade relationships discontinued in the rest of sample period } \\
\hline $\mathrm{P} \& \mathrm{C}$ & 0.37 & 0.54 & 0.71 & 0.81 & 43,570 \\
\hline $\mathrm{FP}$ & 0.34 & 0.51 & 0.67 & 0.77 & 78,356 \\
\hline
\end{tabular}

Note: The difference of failure function between parts \& components and finished products and that between trade relationships discontinued in 1998 and those discontinued in the rest of sample period are significant at the $1 \%$ level using the log-rank test.

\section{Figure 2. Kaplan-Meier Estimates of Failure Functions and Hazard Functions for Intra-Asian Trade in Machineries.}

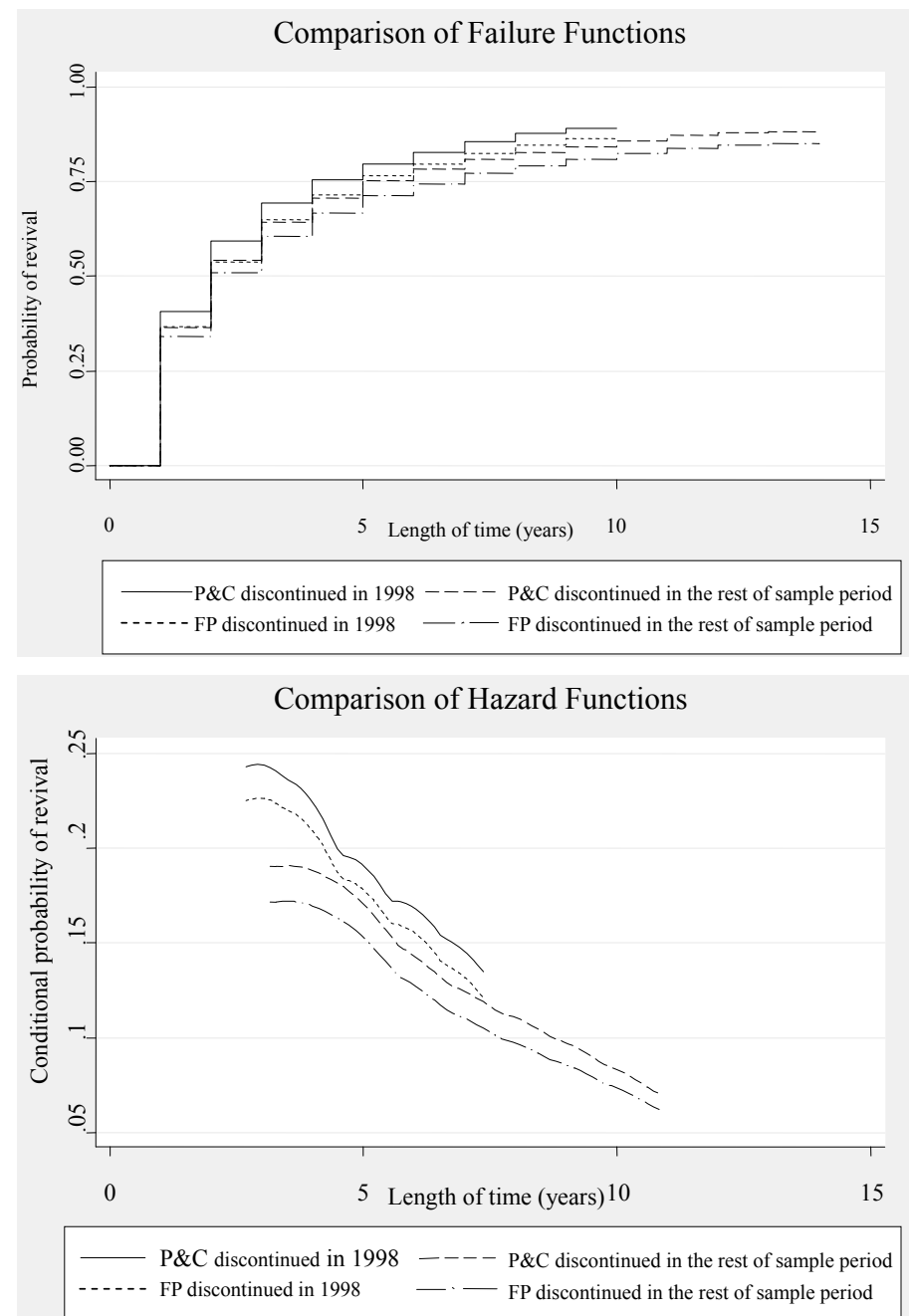


Irrespective of when trade relationships are broken off, the estimated failure curves are upward sloping with a steep slope in the earlier years for both parts \& components and finished products. Among trade relationships discontinued in the same year, the probability of revival is clearly higher for parts \& components than finished products at any point of time. Meanwhile, trade relationships discontinued in 1998 face a higher probability of revival compared to those discontinued in the rest of sample period. Particularly in the case of the trade relationships of parts \& components that were discontinued in 1998, 59\% of them are restored within the first two years, and two thirds of which are restored in just over a year. Besides, three forth of the trade relationships are restored in 2002, at most after a four-year break. Trade relationships restored after a certain period of time may include different firms, so it would be better to treat trade relationships before and after the break as unrelated. Nevertheless, it is striking that a nonnegligible portion of trade relationships was broken off at the time of the Asian crisis, but many of them were restored within just a few years.

The hazard rate here is the conditional probability of the revival of trade relationships given that they have been inactive until the previous year. By the product type, reflecting the difference in the failure rates, the hazard rates are also higher for parts \& components than finished products at any point of time, particularly in the earlier years. The estimated hazard rate is notably high for the trade relationships of parts \& components that were discontinued in 1998, standing at around $25 \%$ in the third year and nearly $15 \%$ even in the seventh year though decreasing over time. More noteworthy is the slope of the hazard curve steeper for the trade relationships discontinued in 1998 than those discontinued in the rest of sample period. From another angle, the distance between the hazard curves is especially large in the earlier years, indicating that the trade relationships discontinued in 1998 are more likely to be restored shortly afterward. These results indicate that, compared to other transactions, trade relationships of parts \& components were less discontinued in 1998, and even when broken off, the transactions were more resilient to a temporary disruption. 


\section{Interpretation and Implication for the Latest Global Crisis}

Trade relationships of parts \& components are more likely to be lasting compared to those of finished products in intra-Asian machinery trade, even after considering the impact of the Asian currency and financial crisis. In addition, although a nonnegligible portion of trade relationships was actually broken off amid the Asian crisis, trade relationships of parts \& components are more likely to be restored shortly compared to those of finished products as well as the transactions that were discontinued in the rest of sample period. A higher probability of survival and revival for parts \& components can be interpreted as indicating the stability and resiliency of the transactions of intermediate goods within international production networks in the Asian region.

Within the networks created, coordinated, and managed by multinational enterprises across borders, each of the fragmented production blocks is not often able to function effectively without coordination between production processes. In other words, the transaction of intermediate goods cannot be realized without coordination with upstream suppliers and/or downstream buyers, irrespective of whether an intermediate good is traded through an intra-firm or arm's length relationship. ${ }^{14}$ Lack of even a single part or component hinders the entire production of the relevant finished product. Moreover, to connect remotely-located production blocks, service link costs including transport costs, telecommunication costs, and coordination costs are required. Service link typically has strong economies of scale in both static and dynamic sense. From the dynamic standpoint, service link plays a critical role in a firm's decision on whether or not to set up the network with sunk costs to invest in a newly fragmented production block.

Given these features of the transaction of intermediate goods within international production networks, firms would put priority not only on lowering production costs but on the stability of trade relationships. In this sense, transactions of intermediate goods within production networks are necessarily based on special relationship, unlike in the

\footnotetext{
${ }^{14}$ Some may wonder if longer-lived trade relationships of intermediate goods reflect that trade of intermediate goods is more driven by intra-firm transactions compared to trade of finished products; however, unfortunately, we cannot obtain detailed trade data classified by type of transaction, i.e., intra-firm or arm's length, as well as by product type.
} 
case of finished products made entirely in one country as well as goods sold on the open market. Due to such relation-specific nature of the transaction, once a trade relationship is established, it would appear that the transaction of intermediate goods within production networks is more lasting and resilient to a short-term shock compared to the other transactions.

The Asian crisis of a decade ago was originated in Asian countries themselves though the latest global crisis originating from the US and Europe has transmitted to Asian countries primarily through the trade channel. Some may suspect that transactions within international production networks were hardly affected by the Asian crisis probably because those transactions depend largely on ultimate demand from outside the region centering on the US. If the US is such an important source of final demand underneath the surface of the development of production networks stretched across Asia, transactions within the networks may be more vulnerable to decline in external demand than to internal economic shock in the region. However, it should be noted that Asia's reliance on the US market even as an export destination of machinery finished products has been rather diminishing.

Table 9 reports the intra- and inter-regional shares of the total exports by Asian countries, the latter of which includes Asian exports to the US, EU, and other regions. The proportion of intra-Asian exports of machinery parts \& components rose from $45 \%$ in 1993 to $57 \%$ in 2007 , whereas the proportion of inter-regional exports declined due to a drastic drop in the US share from $29 \%$ to $14 \%$. More interestingly, as for machinery finished products, the intra-Asian share slightly declined from $28 \%$ to $25 \%$ during the period, but the US share also dropped from $35 \%$ in 2000 to $26 \%$ in 2007. 
Table 9. Composition of Asian Exports by Destination.

\begin{tabular}{|c|c|c|c|c|}
\hline & \multirow{2}{*}{ Destination } & \multicolumn{3}{|c|}{ Share $(\%)$} \\
\hline & & 1993 & 2000 & 2007 \\
\hline \multicolumn{5}{|c|}{ Machineries } \\
\hline \multirow[t]{4}{*}{$\mathrm{P} \& \mathrm{C}$} & Intra-Asia & 44.6 & 49.1 & 57.1 \\
\hline & US & 29.2 & 24.9 & 13.5 \\
\hline & EU & 15.8 & 15.9 & 13.7 \\
\hline & Other regions & 10.4 & 10.1 & 15.8 \\
\hline \multirow[t]{4}{*}{ FP } & Intra-Asia & 27.9 & 26.7 & 24.7 \\
\hline & US & 31.4 & 35.3 & 25.9 \\
\hline & EU & 19.8 & 21.0 & 20.6 \\
\hline & Other regions & 20.8 & 17.0 & 28.7 \\
\hline \multicolumn{5}{|c|}{ Other Manuf. } \\
\hline & Intra-Asia & 49.1 & 48.6 & 42.3 \\
\hline & US & 20.3 & 21.6 & 17.9 \\
\hline & EU & 15.6 & 15.3 & 18.2 \\
\hline & Other regions & 15.0 & 14.6 & 21.7 \\
\hline
\end{tabular}

The growing share of intra-Asian exports of machinery parts \& components cannot be regarded as evidence for independence from external demand if many of them were eventually shipped out of the region, particularly to the US, in the form of finished products. In this regard, however, the destination of the Asian exports of machinery finished products has been diversified by lessening the dependence on the US market. Furthermore, although international trade data do not include machinery finished products manufactured and sold domestically in respective countries, the importance of Asia's own market is increasing steadily in parallel with the continued strong growth of Asian countries. When taking into account all the products manufactured within the region, the proportion of machinery finished products ultimately consumed in the US appears to be much smaller.

Asian countries have built mutually complementary economic ties along with the development of international production networks by taking advantage of regional diversity in income levels and development stages. Surely, the deepening of interdependence via production chains across borders makes it inevitable that an economic shock originating in one country where downstream production block is located will be quickly transmitted to the other countries having the relevant upstream production blocks. Nevertheless, the diversified destinations for the Asian exports of machinery finished products suggest that a country has only to switch to the markets of other countries if its export counterpart's demand for certain finished products is 
deteriorated. As long as the Asia's export destinations other than the country mired in a slump, including Asian countries themselves, sustain growth, a country can switch between potential markets for certain finished products. If so, the transactions of the relevant intermediate goods that are traded within production networks for assembly and manufacturing do not appear to be severely affected by the decreased final demand even in a major export counterpart, say, the US. And, even if trade relationships are broken off due to the external demand shock, the ties built on production networks would still be resilient to a temporary disruption.

\section{Conclusion}

This paper aimed to shed light on the resiliency of international production networks amid the Asian financial and currency crisis as well as confirming its stability after considering adverse effects of the crisis. A series of survival analyses provide an evidence supporting the view that the transactions of intermediate goods within production networks are more likely to be stable and resilient to a temporary disruption compared to the other transactions. Contrary to the public perception of globalizing business activities as foot-loose investments, trade relationships built through production chains are highly stable and resilient to shocks due to the relation-specific nature of the transactions.

Even amid the latest global crisis, the shrinkage of the US and EU markets is not likely to become a profound threat to the stability of international production networks stretched across the Asian region. Production networks will be resilient to the external shocks, backed by the sustained strong growth of Asian own markets, though less economically important trade relationships might be broken off in the process of restructuring the networks to be more efficient or sophisticated 


\section{Appendix A. Trade Data}

This paper basically uses bilateral import data, whenever they are available, from the standpoint of reliability, because country of origin is more closely verified due to tariff regulations though final destination may not be known at time of export. If the import statistics are not available for an exporter-importer pair, the corresponding export statistics are used instead, following Feenstra et al. (2005). In addition, I restrict the sample to the 19,661 country pairs including 152 intra-Asian country pairs, either or both of which have reported trade statistics throughout the sample period.

Trade data for all the years in the sample are originally reported according to or modified to fit the 6-digit level of HS 1992 classification. By using this dataset, although we cannot observe the birth of newly-developed products within a product-line category of the HS 1992 classification, the probability of discontinuing trade relationships will be underestimated, but never be overestimated. More importantly, we do not need to concern about the censoring issue emerging from the complicated mergers and branching of codes due to the update of classification.

Since the annual data at the HS 6-digit level below \$500 (current US\$) are not reported before 2000 , trade flows below $\$ 500$ are treated as if there was no trade at all for all the years in the sample.

\section{Appendix B. Data Sources for Other Variables}

\begin{tabular}{l|l}
\hline \hline \multicolumn{1}{c|}{ Variable } & \multicolumn{1}{c}{ Source } \\
\hline $\begin{array}{l}\text { GDP (constant 2000 US\$) } \\
\text { Per capita GDP (constant 2000 US\$) }\end{array}$ & $\begin{array}{l}\text { The World Bank's World } \\
\text { Development Indicators (WDI) } \\
\text { Online }\end{array}$ \\
\hline $\begin{array}{l}\text { The annual average of nominal exchange rate, } \\
\text { which is deflated by WPI or CPI }(2000=100) \\
\text { for each country }\end{array}$ & $\begin{array}{l}\text { The IMF's International Financial } \\
\text { Statistics (IFS) }\end{array}$ \\
$\begin{array}{l}\text { Initial trade value (US\$), which is deflated by } \\
\text { the US WPI (2000=100) }\end{array}$ & UN Comtrade; the IMF's IFS \\
\hline \hline
\end{tabular}


Figure A1. Kaplan-Meier Estimates of Survival Functions for Intra-Asian Trade: By Different Samples.

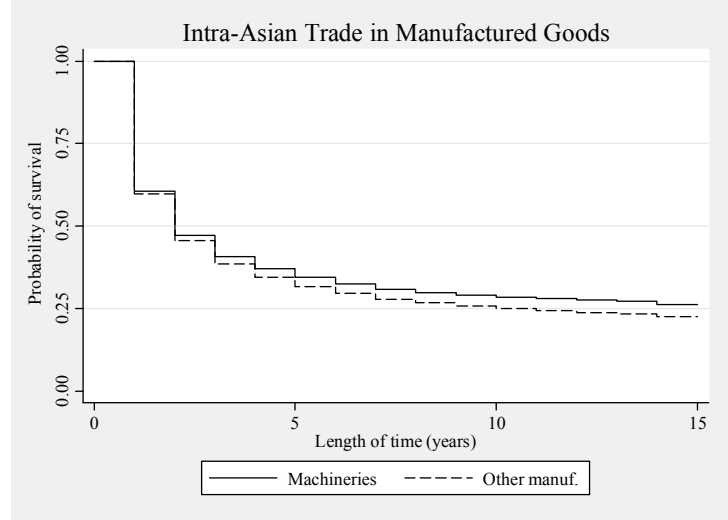

Intra-Asian Trade in Machineries
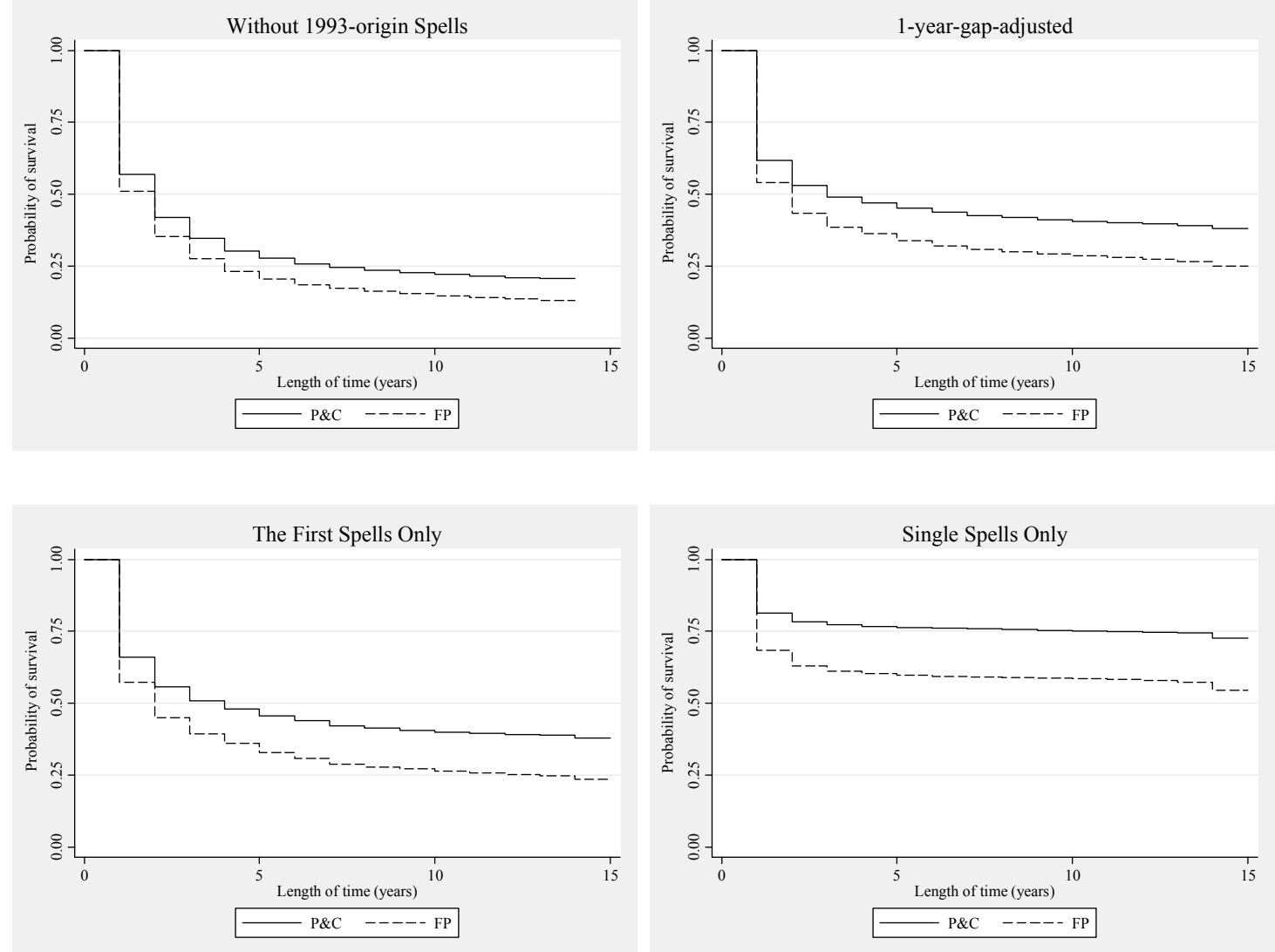
Figure A2. Kaplan-Meier Estimates of Survival Functions for Trade in Machineries: By Different Samples.
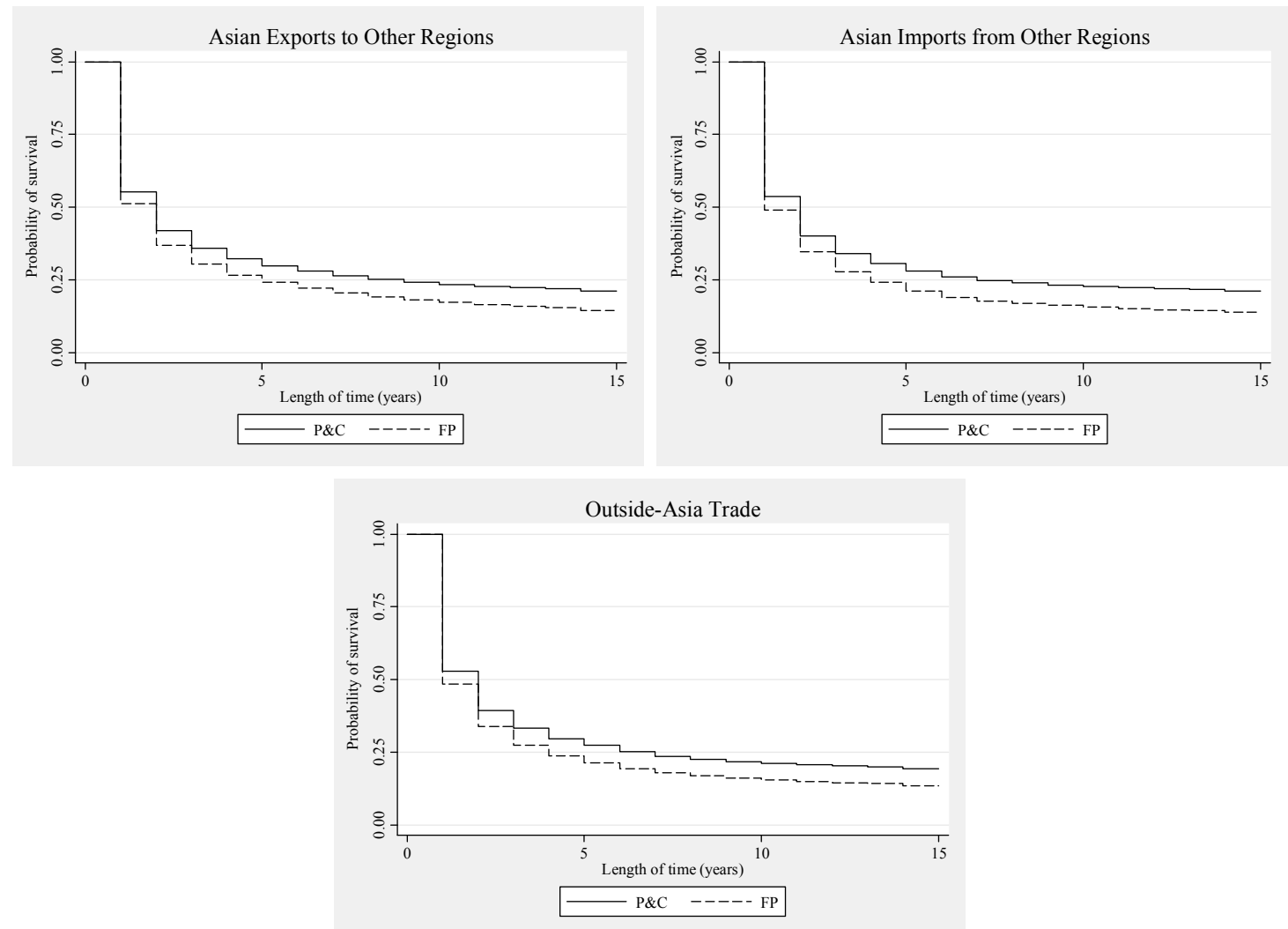

Table A1. Estimated Kaplan-Meier Survival Rates for Intra-Asian Trade: By Different Samples.

\begin{tabular}{ll|c|c|c|c|c|c}
\hline \hline \multirow{2}{*}{ Samples } & \multicolumn{5}{|c|}{ Estimated K-M survival rate } & \multirow{2}{*}{ Obs. } \\
\cline { 3 - 6 } & & $1^{\text {st }}$ year & $2^{\text {nd }}$ year & $4^{\text {th }}$ year & $7^{\text {th }}$ year & $10^{\text {th }}$ year & \\
\hline All manufactured goods & & & & & & \\
All spells & Machineries & 0.61 & 0.47 & 0.37 & 0.31 & 0.29 & 197,561 \\
& Other Manuf. & 0.60 & 0.46 & 0.35 & 0.28 & 0.25 & 436,263 \\
Machineries only & & & & & & \\
Without 1993-origin spells & P \& C & 0.57 & 0.42 & 0.30 & 0.25 & 0.22 & 56,236 \\
& FP & 0.51 & 0.35 & 0.23 & 0.17 & 0.15 & 93,992 \\
1-year-gap-adjusted & P \& C & 0.62 & 0.53 & 0.47 & 0.43 & 0.41 & 71,112 \\
& FP & 0.54 & 0.43 & 0.36 & 0.31 & 0.29 & 110,329 \\
The first spells only & P \& C & 0.66 & 0.56 & 0.48 & 0.42 & 0.40 & 42,893 \\
& FP & 0.57 & 0.45 & 0.36 & 0.29 & 0.26 & 60,561 \\
Single spells only & P \& C & 0.81 & 0.78 & 0.77 & 0.76 & 0.75 & 22,909 \\
& FP & 0.68 & 0.63 & 0.60 & 0.59 & 0.59 & 27,588 \\
\hline \hline
\end{tabular}

Note: The difference of survival function between machineries and other manufactured goods and that between parts \& components and finished products for each sample are significant at the $1 \%$ level using the log-rank test. 
Table A2. Estimated Kaplan-Meier Survival Rates for Trade in Machineries: By Different Samples.

\begin{tabular}{ll|c|c|c|c|c|c}
\hline \hline \multirow{2}{*}{ Samples } & \multicolumn{5}{|c|}{ Estimated K-M survival rate } & \multirow{2}{*}{ Obs. } \\
\cline { 3 - 7 } & & $1^{\text {st }}$ year & $2^{\text {nd }}$ year & $4^{\text {th }}$ year & $7^{\text {th }}$ year & $10^{\text {th }}$ year & \\
\hline East Asian exports to other regions & P\&C & 0.55 & 0.42 & 0.32 & 0.26 & 0.23 & 475,088 \\
& FP & 0.51 & 0.37 & 0.27 & 0.21 & 0.17 & 633,238 \\
East Asian imports to other regions & P\&C & 0.54 & 0.40 & 0.31 & 0.25 & 0.23 & 229,944 \\
& FP & 0.49 & 0.35 & 0.24 & 0.18 & 0.16 & 265,062 \\
Outside-East Asia trade & P\&C & 0.53 & 0.39 & 0.30 & 0.24 & 0.21 & $1,894,462$ \\
& FP & 0.48 & 0.34 & 0.24 & 0.18 & 0.15 & $2,407,660$ \\
\hline \hline
\end{tabular}

Note: The difference of survival function between parts \& components and finished products for each sample is significant at the $1 \%$ level using the log-rank test. 


\section{References}

Asian Development Bank (ADB), (2009). Asian Development Outlook 2009. Manila: ADB.

Ando, M., Kimura, F., (2005). "The formation of International Production and Distribution Networks in East Asia". In: Ito, T., Rose, A. K. (Eds.). International Trade in East Asia. Chicago: University of Chicago Press: 177-213.

Arndt, S.W., Kierzkowski, H., (2001). "Fragmentation: New Production Patterns in the World Economy". Oxford: Oxford University Press.

Athukorala, P.-C., Yamashita, N., (2006). "Production Fragmentation and Trade Integration: East Asia in a Global Context". The North American Journal of Economics and Finance, $17: 233-256$.

Besedeš, T., (2008). "A Search Cost Perspective on Formation and Duration of Trade". Review of International Economics, 16: 835-849.

Besedeš, T., Prusa, T.J., (2006a). "Ins, Outs, and the Duration of Trade". Canadian Journal of Economics, 39: 266-295.

Besedeš, T., Prusa, T.J., (2006b). "Product differentiation and duration of US import trade". Journal of International Economics, 70: 339-358.

Blyde, J., (2008). "What Drives Export Survival?" An analysis on export duration in Latin America. Mimeo.

Breslow, N., (1974). "Covariance Analysis of Censored Survival Data". Biometrics, 30: 89-99.

Deardorff, A.V., (2001). "Fragmentation in Simple Trade Models". The North American Journal of Economics and Finance, 12: 121-137.

Feenstra, R.C., Lipsey, R.E., Deng, H., Ma, A.C., Mo, H., (2005). "World Trade Flows: 1962-2000”. NBER Working Paper No. 11040.

Fukao, K., Ishido, H., Ito, K., (2003). "Vertical Intra-industry Trade and Foreign Direct Investment in East Asia". Journal of the Japanese and International Economies, 17: 468-506.

Jones, R.W., Kierzkowski, H., (1990). "The Role of Services in Production and International trade: A Theoretical Framework". In: Jones, R.W., Krueger, A.O. (Eds.). The Political Economy of International Trade: Essays in Honor of Robert E. Baldwin. Oxford: Basil Blackwell, 31-48.

Kimura, F., (2006). "International Production and Distribution Networks in East Asia: Eighteen Facts, Mechanics, and Policy Implications". Asian Economic Policy Review 1: 326-344.

Kimura, F., Ando, M., (2005). "Two-dimensional Fragmentation in East Asia: Conceptual Framework and Empirics". International Review of Economics and Finance, 14: 317-348.

Nitsch, V., (2009). "Die Another Day: Duration in German Import Trade". Review of World Economics 145: 133-154.

Obashi, A., (2009). "Stability of Production Networks in East Asia: Duration and Survival of Trade. Forthcoming in Japan and the World Economy 


\section{ERIA Discussion Paper Series}

\begin{tabular}{|c|c|c|c|}
\hline No. & Author(s) & Title & Year \\
\hline $2009-21$ & Ayako OBASHI & $\begin{array}{l}\text { Resiliency of Production Networks in Asia: } \\
\text { Evidence from the Asian Crisis }\end{array}$ & $\begin{array}{c}\text { Oct } \\
2009\end{array}$ \\
\hline $2009-20$ & $\begin{array}{l}\text { Mitsuyo ANDO and } \\
\text { Fukunari KIMURA }\end{array}$ & Fragmentation in East Asia: Further Evidence & $\begin{array}{c}\text { Oct } \\
2009\end{array}$ \\
\hline 2009-19 & Xunpeng SHI & $\begin{array}{l}\text { The Prospects for Coal: } \\
\text { Global Experience and Implications for Energy } \\
\text { Policy }\end{array}$ & $\begin{array}{r}\text { Sept } \\
2009\end{array}$ \\
\hline $2009-18$ & Sothea OUM & $\begin{array}{l}\text { Income Distribution and Poverty in a CGE } \\
\text { Framework: A Proposed Methodology }\end{array}$ & $\begin{array}{c}\text { Jun } \\
2009\end{array}$ \\
\hline $2009-17$ & $\begin{array}{l}\text { Erlinda M. MEDALLA } \\
\text { and Jenny BALBOA }\end{array}$ & $\begin{array}{l}\text { ASEAN Rules of Origin: } \\
\text { Lessons and Recommendations for the Best Practice }\end{array}$ & $\begin{array}{c}\text { Jun } \\
2009\end{array}$ \\
\hline $2009-16$ & Masami ISHIDA & Special Economic Zones and Economic Corridors & $\begin{array}{c}\text { Jun } \\
2009\end{array}$ \\
\hline $2009-15$ & Toshihiro KUDO & $\begin{array}{l}\text { Border Area Development in the GMS: } \\
\text { Turning the Periphery into the Center of Growth }\end{array}$ & $\begin{array}{l}\text { May } \\
2009\end{array}$ \\
\hline $2009-14$ & $\begin{array}{l}\text { Claire HOLLWEG and } \\
\text { Marn-Heong WONG }\end{array}$ & $\begin{array}{l}\text { Measuring Regulatory Restrictions in Logistics } \\
\text { Services }\end{array}$ & $\begin{array}{c}\text { Apr } \\
2009\end{array}$ \\
\hline $2009-13$ & Loreli C. De DIOS & Business View on Trade Facilitation & $\begin{array}{c}\text { Apr } \\
2009\end{array}$ \\
\hline $2009-12$ & $\begin{array}{l}\text { Patricia SOURDIN and } \\
\text { Richard POMFRET }\end{array}$ & Monitoring Trade costs in Southeast Asia & $\begin{array}{c}\text { Apr } \\
2009\end{array}$ \\
\hline $2009-11$ & $\begin{array}{l}\text { Philippa DEE and } \\
\text { Huong DINH }\end{array}$ & $\begin{array}{l}\text { Barriers to Trade in Health and Financial Services in } \\
\text { ASEAN }\end{array}$ & $\begin{array}{c}\text { Apr } \\
2009\end{array}$ \\
\hline $2009-10$ & Sayuri SHIRAI & $\begin{array}{l}\text { The Impact of the US Subprime Mortgage Crisis on } \\
\text { the World and East Asia -Through Analyses of } \\
\text { Cross-border Capital Movements- }\end{array}$ & $\begin{array}{l}\text { Apr } \\
2009\end{array}$ \\
\hline 2009-09 & $\begin{array}{l}\text { Mitsuyo ANDO and } \\
\text { Akie IRIYAMA }\end{array}$ & $\begin{array}{l}\text { International Production Networks and Export/Import } \\
\text { Responsiveness to Exchange Rates: } \\
\text { The Case of Japanese Manufacturing Firms }\end{array}$ & $\begin{array}{l}\text { Mar } \\
2009\end{array}$ \\
\hline
\end{tabular}




\begin{tabular}{|c|c|c|c|}
\hline 2009-08 & $\begin{array}{l}\text { Archanun } \\
\text { KOHPAIBOON }\end{array}$ & $\begin{array}{l}\text { Vertical and Horizontal FDI Technology Spillovers: } \\
\text { Evidence from Thai Manufacturing }\end{array}$ & $\begin{array}{l}\text { Mar } \\
2009\end{array}$ \\
\hline 2009-07 & $\begin{array}{l}\text { Kazunobu HAYAKAWA, } \\
\text { Fukunari KIMURA, and } \\
\text { Toshiyuki MATSUURA }\end{array}$ & $\begin{array}{l}\text { Gains from Fragmentation at the Firm Level: } \\
\text { Evidence from Japanese Multinationals in East Asia }\end{array}$ & $\begin{array}{l}\text { Mar } \\
2009\end{array}$ \\
\hline 2009-06 & Dionisius A. NARJOKO & $\begin{array}{l}\text { Plant Entry in a More Liberalised Industrialisation } \\
\text { Process: An Experience of Indonesian } \\
\text { Manufacturing during the } 1990 \text { s }\end{array}$ & $\begin{array}{l}\text { Mar } \\
2009\end{array}$ \\
\hline $2009-05$ & $\begin{array}{l}\text { Kazunobu HAYAKAWA, } \\
\text { Fukunari KIMURA, and } \\
\text { Tomohiro MACHIKITA }\end{array}$ & Firm-level Analysis of Globalization: A Survey & $\begin{array}{l}\text { Mar } \\
2009\end{array}$ \\
\hline 2009-04 & $\begin{array}{l}\text { Chin Hee HAHN and } \\
\text { Chang-Gyun PARK }\end{array}$ & $\begin{array}{l}\text { Learning-by-exporting in Korean Manufacturing: } \\
\text { A Plant-level Analysis }\end{array}$ & $\begin{array}{l}\text { Mar } \\
2009\end{array}$ \\
\hline 2009-03 & Ayako OBASHI & $\begin{array}{l}\text { Stability of Production Networks in East Asia: } \\
\text { Duration and Survival of Trade }\end{array}$ & $\begin{array}{l}\text { Mar } \\
2009\end{array}$ \\
\hline 2009-02 & Fukunari KIMURA & $\begin{array}{l}\text { The Spatial Structure of Production/Distribution } \\
\text { Networks and Its Implication for Technology } \\
\text { Transfers and Spillovers }\end{array}$ & $\begin{array}{l}\text { Mar } \\
2009\end{array}$ \\
\hline 2009-01 & $\begin{array}{l}\text { Fukunari KIMURA and } \\
\text { Ayako OBASHI }\end{array}$ & $\begin{array}{l}\text { International Production Networks: } \\
\text { Comparison between China and ASEAN }\end{array}$ & $\begin{array}{c}\text { Jan } \\
2009\end{array}$ \\
\hline 2008-03 & $\begin{array}{l}\text { Kazunobu HAYAKAWA } \\
\text { and Fukunari KIMURA }\end{array}$ & $\begin{array}{l}\text { The Effect of Exchange Rate Volatility on } \\
\text { International Trade in East Asia }\end{array}$ & $\begin{array}{c}\text { Dec } \\
2008\end{array}$ \\
\hline 2008-02 & $\begin{array}{l}\text { Satoru KUMAGAI, } \\
\text { Toshitaka GOKAN, } \\
\text { Ikumo ISONO, and } \\
\text { Souknilanh KEOLA }\end{array}$ & $\begin{array}{l}\text { Predicting Long-Term Effects of Infrastructure } \\
\text { Development Projects in Continental South East } \\
\text { Asia: IDE Geographical Simulation Model }\end{array}$ & $\begin{array}{c}\text { Dec } \\
2008\end{array}$ \\
\hline 2008-01 & $\begin{array}{l}\text { Kazunobu HAYAKAWA, } \\
\text { Fukunari KIMURA, and } \\
\text { Tomohiro MACHIKITA }\end{array}$ & Firm-level Analysis of Globalization: & $\begin{array}{c}\text { Dec } \\
2008\end{array}$ \\
\hline
\end{tabular}

